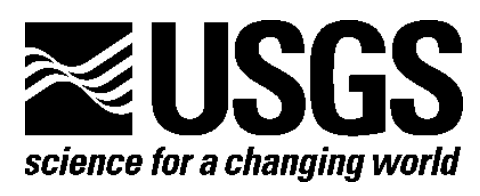

\title{
Publications of the Volcano Hazards Program 2013
}

By Manuel Nathenson

Open-File Report 2015-1109

U.S. Department of the Interior U.S. Geological Survey 


\section{U.S. Department of the Interior \\ SALLY JEWELL, Secretary}

\section{U.S. Geological Survey}

Suzette M. Kimball, Acting Director

\section{U.S. Geological Survey, Reston, Virginia: 2015}

For more information on the USGS-the Federal source for science about the Earth, its natural and living resources, natural hazards, and the environment-visit http://www.usgs.gov/ or call 1-888-ASK-USGS (1-888-275-8747).

For an overview of USGS information products, including maps, imagery, and publications, visit http://www.usgs.gov/pubprod/.

Any use of trade, firm, or product names is for descriptive purposes only and does not imply endorsement by the U.S. Government.

Although this information product, for the most part, is in the public domain, it also may contain copyrighted materials as noted in the text. Permission to reproduce copyrighted items must be secured from the copyright owner.

Suggested citation:

Nathenson, Manuel, 2015, Publications of the Volcano Hazards Program 2013: U.S. Geological Survey Open-File Report 2015-1109, 13 p., http://dx.doi.org/10.3133/ofr20151109.

ISSN 2331-1258 (online) 


\section{Publications of the Volcano Hazards Program 2013}

By Manuel Nathenson

The Volcano Hazards Program of the U.S. Geological Survey (USGS) is part of the Natural Hazards activity, as funded by Congressional appropriation. Investigations are carried out by the USGS and with cooperators at the Alaska Division of Geological and Geophysical Surveys, University of Alaska Fairbanks Geophysical Institute, University of Hawai 'i Mānoa and Hilo, University of Utah, and University of Washington Geophysics Program. This report lists publications from all of these institutions.

Only published papers and maps are included here; abstracts presented at scientific meetings are omitted. Publication dates are based on year of issue, with no attempt to assign them to a fiscal year. 


\section{Volcano Hazards Program Publications 2013}

Ankney, M.E., Johnson, C.M., Bacon, C.R., Beard, B.L., and Jicha, B.R., 2013, Distinguishing lower and upper crustal processes in magmas erupted during the buildup to the 7.7 ka climactic eruption of Mount Mazama, Crater Lake, Oregon, using ${ }^{238} \mathrm{U}$ ${ }^{230}$ Th disequilibria: Contributions to Mineralogy and Petrology, v. 166, p. 563-585.

Auker, M.R., Sparks, R.S.J., Siebert, Lee, Crosweller, H.S., and Ewert, John, 2013, A statistical analysis of the global historical volcanic fatalities record: Journal of Applied Volcanology, v. 2, no. 2, 24 p.

Bagnardi, Marco, Amelung, Falk, and Poland, M.P., 2013, A new model for the growth of basaltic shields based on deformation of Fernandina volcano, Galápagos Islands: Earth and Planetary Science Letters, v. 377-378, p. 358-366.

Ballmer, Silke, Wolfe, C.J., Okubo, P.G., Haney, M.M., and Thurber, C.H., 2013, Ambient seismic noise interferometry in Hawai' $i$ reveals long-range observability of volcanic tremor: Geophysical Journal International, v. 194, p. 512-523.

Bard, J.A., Ramsey, D.W., MacLeod, N.S., Sherrod, D.R., Chitwood, L.A., and Jensen, R.A., 2013, Database for the Geologic Map of Newberry Volcano, Deschutes, Klamath, and Lake Counties, Oregon: U.S. Geological Survey Data Series 771, data files, http://pubs.usgs.gov/ds/771/.

Battaglia, Maurizio, Cervelli, P.F., and Murray, J.R., 2013, dMODELS: A MATLAB software package for modeling crustal deformation near active faults and volcanic centers: Journal of Volcanology and Geothermal Research, v. 254, p. 1-4.

Battaglia, Maurizio, Cervelli, P.F., and Murray-Muraleda, J.R., 2013, Modeling crustal deformation near active faults and volcanic centers - A catalog of deformation models: U.S. Geological Survey Techniques and Methods, book 13, chap. B1, 96 p., http://pubs.usgs.gov/tm/13/b1.

Beeler, N. M., Thomas, A., Bürgmann, R., and Shelly, D. R., 2013, Inferring fault rheology from low-frequency earthquakes on the San Andreas: Journal of Geophysical Research Solid Earth, v. 118, p. 5976-5990.

Behnke, S.A., Thomas, R.J., McNutt, S.R., Schneider, D.J., Krehbiel, P.R., Rison, William, and Edens, H.E., 2013, Observations of volcanic lightning during the 2009 eruption of Redoubt Volcano, in Waythomas, C.F., and Webley, P.W., eds., The 2009 eruption of Redoubt Volcano, Alaska: Journal of Volcanology and Geothermal Research, v. 259, p. 214-234.

Blatter, D.L., Sisson, T.W., and Hankins, W.B., 2013, Crystallization of oxidized, moderately hydrous arc basalt at mid- to lower-crustal pressures-Implications for andesite genesis: Contributions to Mineralogy and Petrology, v. 166, p. 861-886.

Bleick, H.A., Coombs, M.L., Cervelli, P.F., Bull, K.F., and Wessels, R.L., 2013, Volcano-Ice interactions precursory to the 2009 eruption of Redoubt Volcano, Alaska, in Waythomas, C.F., and Webley, P.W., eds., The 2009 eruption of Redoubt Volcano, Alaska: Journal of Volcanology and Geothermal Research, v. 259, p. 373-388.

Brown, J.R., Prejean, S.G., Beroza, G.C., Gomberg, J.S., and Haeussler, P.J., 2013, Deep low-frequency earthquakes in tectonic tremor along the Alaska-Aleutian subduction zone: Journal of Geophysical Research Solid Earth, v. 118, p. 1079-1090.

Brown, S.T., Kennedy, B.M., DePaolo, D.J., Hurwitz, Shaul, and Evans, W.C., 2013, Ca, $\mathrm{Sr}, \mathrm{O}$ and $\mathrm{D}$ isotope approach to defining the chemical evolution of hydrothermal 
fluids - Example from Long Valley, CA, USA: Geochimica et Cosmochimica Acta, v. 122, p. 209-225.

Bull, K.F., and Buurman, Helena, 2013, An overview of the 2009 eruption of Redoubt Volcano, Alaska, in Waythomas, C.F., and Webley, P.W., eds., The 2009 eruption of Redoubt Volcano, Alaska: Journal of Volcanology and Geothermal Research, v. 259, p. $2-15$.

Bull, K.F., Anderson, S.W., Diefenbach, A.K., Wessels, R.L., and Henton, S.M., 2013, Emplacement of the final lava dome of the 2009 eruption of Redoubt Volcano, Alaska, in Waythomas, C.F., and Webley, P.W., eds., The 2009 eruption of Redoubt Volcano, Alaska: Journal of Volcanology and Geothermal Research, v. 259, p. 334-348.

Bursik, M., and Sieh, K., 2013, Digital database of the Holocene tephras of the MonoInyo Craters, California: U.S. Geological Survey Data Series 758, 6 p., data files, http://pubs.usgs.gov/ds/758/.

Buurman, Helena, and West, M.E., 2013, Magma fracture and hybrid earthquakes in the conduit of Augustine Volcano: Geophysical Research Letters, v. 40, p. 6038-6042.

Buurman, Helena, West, M.E., and Roman, D.C., 2013, Using repeating volcano-tectonic earthquakes to track post-eruptive activity in the conduit system at Redoubt Volcano, Alaska: Geology, v. 41, p. 511-514.

Buurman, Helena, West, M.E., and Thompson, Glenn, 2013, The seismicity of the 2009 Redoubt eruption, in Waythomas, C.F., and Webley, P.W., eds., The 2009 eruption of Redoubt Volcano, Alaska: Journal of Volcanology and Geothermal Research, v. 259, p. $16-30$.

Carbone, Daniele, Poland, M.P., Patrick, M.R., and Orr, T.R., 2013, Continuous gravity measurements reveal a low-density lava lake at Kîlauea Volcano, Hawai' $i$ : Earth and Planetary Science Letters, v. 376, p. 178-185.

Carey, R.J., Manga, Michael, Degruyter, Wim, Gonnermann, Helge, Swanson, Donald, Houghton, Bruce, Orr, Tim, and Patrick, Matthew, 2013, Convection in a volcanic conduit recorded by bubbles: Geology, v. 41, p. 395-398.

Chang, Wu-Lung, Smith, R.B., and Puskas, C.M., 2013, Effects of lithospheric viscoelastic relaxation on the contemporary deformation following the $1959 M_{\mathrm{w}} 7.3$ Hebgen Lake, Montana, earthquake and other areas of the intermountain seismic belt: Geochemistry, Geophysics, Geosystems, v. 14, 17 p.

Chen, Heng, Savage, P.S., Teng, Fang-Zehn, Helz, R.T., and Moynier, Frédéric, 2013, Zinc isotope fractionation during magmatic differentiation and the isotopic composition of the bulk Earth: Earth and Planetary Science Letters, v. 369-370, p. 34-42.

Chouet, Bernard, 2013, Introduction to quantitative volcano seismology-Fluid-driven sources, chap. 15 of Fagents, S.A., Gregg, T.K.P., and Lopes, R.M.C., eds., Modeling volcanic processes - The physics and mathematics of volcanism: New York, Cambridge University Press, p. 331-358.

Chouet, Bernard, and Dawson, Phillip, 2013, Very long period conduit oscillations induced by rockfalls at Kilauea Volcano, Hawaii: Journal of Geophysical Research Solid Earth, v. 118, p. 5352-5371.

Chouet, B.A., and Matoza, R.S., 2013, A multi-decadal view of seismic methods for detecting precursors of magma movement and eruption: Journal of Volcanology and Geothermal Research, v. 252, p. 108-175. 
Coombs, M.L., Sisson, T.W., Bleick, H.A., Henton, S.M., Nye, C.J., Payne, A.L., Cameron, C.E., Larsen, J.F., Wallace, K.L., and Bull, K.F., 2013, Andesites of the 2009 eruption of Redoubt Volcano, Alaska, in Waythomas, C.F., and Webley, P.W., eds., The 2009 eruption of Redoubt Volcano, Alaska: Journal of Volcanology and Geothermal Research, v. 259, p. 349-372.

Costa, Fidel, Andreastuti, Supriyati, Bouvet de Maisonneuve, Caroline, and Pallister, J.S., 2013, Petrological insights into the storage conditions, and magmatic processes that yielded the centennial 2010 Merapi explosive eruption, in Jousset, Philippe, Pallister, John, and Surono, eds., The 2010 eruption of Merapi volcano: Journal of Volcanology and Geothermal Research, v. 261, p. 209-235.

De Angelis, S.H., Larsen, Jessica, and Coombs, Michelle, 2013, Pre-eruptive magmatic conditions at Augustine Volcano, Alaska, 2006-Evidence from amphibole geochemistry and textures: Journal of Petrology, v. 54, p. 1939-1961.

Denlinger, R.P., Webley, Peter, Mastin, L.G., and Schwaiger, Hans, 2013, A Bayesian method to rank different model forecasts of the same volcanic ash cloud, in Lin, John, Brunner, Dominik, Gerbig, Christoph, Stohl, Andreas, Luhar, Ashok, and Webley, Peter, eds., Lagrangian modeling of the atmosphere: American Geophysical Union, Geophysical Monograph 200, Washington, p. 299-310.

Diefenbach, A.K., Bull, K.F., Wessels, R.L., and McGimsey, R.G., 2013, Photogrammetric monitoring of lava dome growth during the 2009 eruption of Redoubt Volcano, in Waythomas, C.F., and Webley, P.W., eds., The 2009 eruption of Redoubt Volcano, Alaska: Journal of Volcanology and Geothermal Research, v. 259, p. 308316.

Dixon, J.P., Stihler, S.D., Power, J.A., Haney, Matt, Parker, Tom, Searcy, C.K., and Prejean, Stephanie, 2013, Catalog of earthquake hypocenters at Alaskan volcanoes: January 1 through December 31, 2012: U.S. Geological Survey Data Series 789, 84 p., data files, http://pubs.usgs.gov/ds/789/.

Dmitrieva, Ksenia, Hotovec-Ellis, A.J., Prejean, Stephanie, and Dunham, E.M., 2013, Frictional-faulting model for harmonic tremor before Redoubt Volcano eruptions: Nature Geoscience, v. 6, p. 652-656.

Dzurisin, Daniel, Driedger, C.L., and Faust, L.M., 2013, Mount St. Helens, 1980 to now-What's going on?: U.S. Geological Survey Fact Sheet 2013-3014, 6 p., videos, http://pubs.usgs.gov/fs/2013/3014/.

Edmonds, M., Sides, I.R., Swanson, D.A., Werner, C., Martin, R.S., Mather, T.A., Herd, R.A., Jones, R.L., Mead, M.I., Sawyer, G., Roberts, T.J., Sutton, A.J., and Elias, T., 2013, Magma storage, transport and degassing during the 2008-10 summit eruption at Kīlauea Volcano, Hawai'i: Geochimica et Cosmochimica Acta, v. 123, p. 284-301. Ekstrand, A.L., Webley, P.W., Garay, M.J., Dehn, Jonathan, Prakash, Anupma, Nelson, D.L., Dean, K.G., and Steensen, Torge, 2013, A multi-sensor plume height analysis of the 2009 Redoubt eruption, in Waythomas, C.F., and Webley, P.W., eds., The 2009 eruption of Redoubt Volcano, Alaska: Journal of Volcanology and Geothermal Research, v. 259, p. 170-184.

Evans, W.C., Hurwitz, S., Bergfeld, D., Lewicki, J., Huebner, M.A., Williams, C.F., and Brown, S.T., 2013, Water-rock interaction in the Long Valley Caldera (USA), in Hellmann, Roland, and Pitsch, Helmut, eds., Proceedings of the Fourteenth 
International Symposium on Water-Rock Interaction: Procedia Earth and Planetary Science, v. 7, p. 252-255.

Fee, David, McNutt, S.R., Lopez, T.M., Arnoult, K.M., Szuberla, C.A.L., and Olson, J.V., 2013, Combining local and remote infrasound recordings from the 2009 Redoubt Volcano eruption, in Waythomas, C.F., and Webley, P.W., eds., The 2009 eruption of Redoubt Volcano, Alaska: Journal of Volcanology and Geothermal Research, v. 259, p. 100-114.

Field, L., Blundy, J., Calvert, A., and Yirgu, G., 2013, Magmatic history of Dabbahu, a composite volcano in the Afar Rift, Ethiopia: Geological Society of America Bulletin, v. 125, p. $128-147$.

Flinders, A.F., Ito, Garrett, Garcia, M.O., Sinton, J.M., Kauahikaua, Jim, and Taylor, Brian, 2013, Intrusive dike complexes, cumulate cores, and the extrusive growth of Hawaiian volcanoes: Geophysical Research Letters, v. 40, p. 3367-3373.

Foster, James, Kealy, John, Cherubini, Tiziana, Businger, Steven, Lu, Zhong, and Murphy, Michael, 2013, The utility of atmospheric analyses for the mitigation of artifacts in InSAR: Journal of Geophysical Research Solid Earth, v. 118, p. 748-758.

Gardner, W.P., Susong, D.D., Solomon, D.K., and Heasler, H.P., 2013, Using environmental tracers and numerical simulation to investigate regional hydrothermal basins_-Norris Geyser Basin area, Yellowstone National Park, USA: Journal of Geophysical Research Solid Earth, v. 118, p. 2777-2787.

Gates, J.B., 2013, Helium sources to groundwater in active volcanic terrain, and implications for tritium-helium dating at Mount St. Helens, in Hellmann, Roland, and Pitsch, Helmut, eds., Proceedings of the Fourteenth International Symposium on Water-Rock Interaction: Procedia Earth and Planetary Science, v. 7, p. 292-295. Gomberg, Joan, and Prejean, Stephanie, 2013, Triggered tremor sweet spots in Alaska: Journal of Geophysical Research Solid Earth, v. 118, p. 6203-6218.

Grapenthin, Ronni, Freymueller, J.T., and Kaufman, A.M., 2013, Geodetic observations during the 2009 eruption of Redoubt Volcano, Alaska, in Waythomas, C.F., and Webley, P.W., eds., The 2009 eruption of Redoubt Volcano, Alaska: Journal of Volcanology and Geothermal Research, v. 259, p. 115-132.

Greene, A.R., Garcia, M.O., Becker, Nathan, and Poland, Michael, 2013, Natural hazards on the Island of Hawai'i: Carleton College Science Education and Resource Center, documents, 4 plates, accessed October 17, 2013, at http://serc.carleton.edu/NAGTWorkshops/activities/74390.html.

Guffanti, Marianne, and Miller, T. P., 2013, A volcanic activity alert-level system for aviation-Review of its development and application in Alaska: Natural Hazards, v. 69, p. 1519-1533.

Haney, M.M., Chouet, B.A., Dawson, P.B., and Power, J.A., 2013, Source characterization for an explosion during the 2009 eruption of Redoubt Volcano from very-long-period seismic waves, in Waythomas, C.F., and Webley, P.W., eds., The 2009 eruption of Redoubt Volcano, Alaska: Journal of Volcanology and Geothermal Research, v. 259, p. 77-88.

Hickson, C.J., Spurgeon, T.C., and Tilling, R.I., 2013, Eruption types (volcanic eruptions), in Bobrowsky, P.T., ed., Encyclopedia of Natural Hazards: Dordrecht, The Netherlands, Springer, p. 290-293. 
Hickson, C.J., Spurgeon, T.C., and Tilling, R.I., 2013, Magma, in Bobrowsky, P.T., ed., Encyclopedia of Natural Hazards: Dordrecht, The Netherlands, Springer, p. 639-640. Hickson, C.J., Spurgeon, T.C., and Tilling, R.I., 2013, Nuée ardente, in Bobrowsky, P.T., ed., Encyclopedia of Natural Hazards: Dordrecht, The Netherlands, Springer, p. 740741.

Hickson C., Spurgeon T., Tilling, R., and Adam, P., 2013, Factors influencing volcanic hazards and the morphology of volcanic landforms, in James, Allen, Harden, Carol, and Clague, John, eds., Geomorphology of human disturbances, climate change, and natural hazards: San Diego, Academic Press, Treatise on Geomorphology, v. 13, p. 219-242.

Hill, D.P., Peng, Z., Shelly, D.R., and Aiken, C., 2013, S-wave triggering of tremor beneath the Parkfield, California, section of the San Andreas Fault by the 2011 Tohoku, Japan, earthquake-Observations and theory: Bulletin of the Seismological Society of America, v. 103, p. 1541-1550.

Holmes, R.R., Jr., Jones, L.M., Eidenshink, J.C., Godt, J.W., Kirby, S.H., Love, J.J., Neal, C.A., Plant, N.G., Plunkett, M.L., Weaver, C.S., Wein, Anne, and Perry, S.C., 2013, U.S. Geological Survey natural hazards science strategy_-Promoting the safety, security, and economic well-being of the nation: U.S. Geological Survey Circular 1383-F, 79 p., http://pubs.usgs.gov/circ/1383f/.

Hotovec, A.J., Prejean, S.G., Vidale, J.E., and Gomberg, Joan, 2013, Strongly gliding harmonic tremor during the 2009 eruption of Redoubt Volcano, in Waythomas, C.F., and Webley, P.W., eds., The 2009 eruption of Redoubt Volcano, Alaska: Journal of Volcanology and Geothermal Research, v. 259, p. 89-99.

Houghton, B.F., Swanson, D.A., Rausch, J., Carey, R.J., Fagents, S.A., and Orr, T.R., 2013, Pushing the Volcanic Explosivity Index to its limit and beyond - Constraints from exceptionally weak explosive eruptions at Kîlauea in 2008: Geology, v. 41, p. 627-630.

Iverson, R.M., 2013, Mechanics of debris flows and rock avalanches, in Fernando, H.J.S., ed., Handbook of environmental fluid dynamics, v. 1: Boca Raton, CRC Press, p. 573587.

Iverson, R.M., 2013, Discussion of "Numerical study on entrainment of bed material into rapid landslides" by M. Pirulli and M. Pastor: Géotechnique, v. 63, p. 887-888.

Ji, K.H., Herring, T.A., and Llenos, A.L., 2013, Near real-time monitoring of volcanic surface deformation from GPS measurements at Long Valley Caldera, California: Geophysical Research Letters, v. 40, p. 1054-1058.

Ji, Lingyun, Lu, Zhong, Dzurisin, Daniel, and Senyukov, Sergey, 2013, Pre-eruption deformation caused by dike intrusion beneath Kizimen volcano, Kamchatka, Russia, observed by InSAR: Journal of Volcanology and Geothermal Research, v. 256, p. 8795.

Johnson, J.H., and Poland, M.P., 2013, Seismic detection of increased degassing prior to Kîlauea's 2008 summit explosion: Nature Communications, v. 4, article 1668. [doi:10.1038/ncomms2703.]

Johnson, K.M., Shelly, D.R., and Bradley, A.M., 2013, Simulations of tremor-related creep reveal a weak crustal root of the San Andreas Fault: Geophysical Research Letters, v. 40, p. 1300-1305. 
Jousset, Philippe, Pallister, John, and Surono, eds., 2013, The 2010 eruption of Merapi volcano: Journal of Volcanology and Geothermal Research, v. 261, 387 p.

Jousset, Philippe, Pallister, John, and Surono, 2013, The 2010 eruption of Merapi volcano, in Jousset, Philippe, Pallister, John, and Surono, eds., The 2010 eruption of Merapi volcano: Journal of Volcanology and Geothermal Research, v. 261, p. 1-6.

Karlstrom, Leif, Hurwitz, Shaul, Sohn, Robert, Vandemeulebrouck, Jean, Murphy, Fred, Rudolph, M.L., Johnston, M.J.S., Manga, Michael, and McCleskey, R.B., 2013, Eruptions at Lone Star Geyser, Yellowstone National Park, USA - 1. Energetics and eruption dynamics: Journal of Geophysical Research Solid Earth, v. 118, p. 40484062.

Kelly, P.J., Kern, Christoph, Roberts, T.J., Lopez, Taryn, Werner, Cynthia, and Aiuppa, Alessandro, 2013, Rapid chemical evolution of tropospheric volcanic emissions from Redoubt Volcano, Alaska, based on observations of ozone and halogen-containing gases, in Waythomas, C.F., and Webley, P.W., eds., The 2009 eruption of Redoubt Volcano, Alaska: Journal of Volcanology and Geothermal Research, v. 259, p. 317333.

Kendrick, J.E., Smith, Rosanna, Sammonds, Peter, Meredith, P.G., Dainty, Matthew, and Pallister, J.S., 2013, The influence of thermal and cyclic stressing on the strength of rocks from Mount St. Helens, Washington: Bulletin of Volcanology, v. 75, article 728, $12 \mathrm{p}$.

Kern, Christoph, Werner, Cynthia, Elias, Tamar, Sutton, A.J., and Lübcke, Peter, 2013, Applying UV cameras for $\mathrm{SO}_{2}$ detection to distant or optically thick volcanic plumes: Journal of Volcanology and Geothermal Research, v. 262, p. 80-89.

Ketner, Dane, and Power, John, 2013, Characterization of seismic events during the 2009 eruption of Redoubt Volcano, Alaska, in Waythomas, C.F., and Webley, P.W., eds., The 2009 eruption of Redoubt Volcano, Alaska: Journal of Volcanology and Geothermal Research, v. 259, p. 45-62.

Koeppen, W.C., Patrick, M., Orr, T., Sutton, A.J., Dow, D., and Wright, R., 2013, Constraints on the partitioning of Kîlauea's lavas between surface and tube flows, estimated from infrared satellite data, sulfur dioxide emission rates, and field observations: Bulletin of Volcanology, v. 75, article 716, 18 p.

Lara, L.E., Moreno, Rodrigo, Amigo, Álvaro, Hoblitt, R.P., and Pierson, T.C., 2013, Late Holocene history of Chaitén Volcano-New evidence for a 17th century eruption: Andean Geology, v. 40, p. 249-261.

Larsen, J.F., Śliwinski, M.G., Nye, Christopher, Cameron, Cheryl, and Schaefer, J.R., 2013, The 2008 eruption of Okmok Volcano, Alaska-Petrological and geochemical constraints on the subsurface magma plumbing system: Journal of Volcanology and Geothermal Research, v. 264, p. 85-106.

Lee, Chang-Wook, Lu, Zhong, Won, Joong-Sun, Jung, Hyung-Sun, and Dzurisin, Daniel, 2013, Dynamic deformation of Seguam Island, Alaska, 1992-2008, from multiinterferogram InSAR processing: Journal of Volcanology and Geothermal Research, v. 260, p. 43-51.

Lehto, H.L., Roman, D.C., and Moran, S.C., 2013, Source mechanisms of persistent shallow earthquakes during eruptive and non-eruptive periods between 1981 and 2011 at Mount St. Helens, Washington: Journal of Volcanology and Geothermal Research, v. 256, p. 1-15. 
Lipman, P.W., and Calvert, A.T., 2013, Modeling volcano growth on the Island of Hawaii: deep-water perspectives: Geosphere, v. 9, p. 1348-1383.

Lipman, P.W., McIntosh, W.C., and Zimmerer, M., 2013, From ignimbrite to batholith, northeastern San Juan Mountains, Colorado-Bonanza, Cochetopa Park, and North Pass calderas, in Abbott, L.D., and Hancock, G.S., eds., Classic concepts and new directions-Exploring 125 years of GSA discoveries in the Rocky Mountains region: Geological Society of America Field Guides 33, p. 357-388.

Logan, Matthew, and Iverson, R.M., 2007, revised 2013, Video documentation of experiments at the USGS debris-flow flume 1992-2006 (amended to include 20072013): U.S. Geological Survey Open-File Report 2007-1315 v. 1.3, videos, http://pubs.usgs.gov/of/2007/1315/.

Lopez, T.M., 2013, Characterization and interpretation of volcanic activity at Redoubt, Bezymianny and Karymsky Volcanoes through direct and remote measurements of volcanic emissions: University of Alaska Fairbanks Ph.D. dissertation, 225 p., accessed May 11, 2015, at http://www.avo.alaska.edu/downloads/get_file.php?id=4721.

Lopez, Taryn, Carn, Simon, Werner, Cynthia, Fee, David, Kelly, Peter, Doukas, Michael, Pfeffer, Melissa, Webley, Peter, Cahill, Catherine, and Schneider, David, 2013, Evaluation of Redoubt Volcano's sulfur dioxide emissions by the Ozone Monitoring Instrument, in Waythomas, C.F., and Webley, P.W., eds., The 2009 eruption of Redoubt Volcano, Alaska: Journal of Volcanology and Geothermal Research, v. 259, p. 290-307.

López, Taryn, Ushakov, Sergey, Izbekov, Pavel, Tassi, Franco, Cahill, Cathy, Neill, Owen, and Werner, Cynthia, 2013, Constraints on magma processes, subsurface conditions, and total volatile flux at Bezymianny Volcano in 2007-2010 from direct and remote volcanic gas measurements, in Izbekov, Pavel, Gordeev, Evgenii, Eichelberger, John, and West, Michael, eds., Magma system response to edifice collapse: Journal of Volcanology and Geothermal Research, v. 263, p. 92-107.

Lowenstern, J.B., ed., 2013, Abstracts for the October 2012 meeting on Volcanism in the American Southwest, Flagstaff, Arizona: U.S. Geological Survey Open-File Report 2013-1026, 39 p., http://pubs.usgs.gov/of/2013/1026/.

Lowenstern, J.B., and Pitcher, B.W, 2013, Analysis of $\mathrm{H}_{2} \mathrm{O}$ in silicate glass using attenuated total reflectance (ATR) micro-FTIR spectroscopy: American Mineralogist, v. 98, p. 1660-1668.

Lu, Zhong, Jung, H.-S., Zhang, Lei, Lee, Wonjin, Lee, C.-W., and Dzurisin, Daniel, 2013, Digital elevation model generation from satellite interferometric synthetic aperture radar, chap. 5 of Yang, Xiaojun, and Li, Jonathan, eds., Advances in mapping from remote sensor imagery-Techniques and applications: Boca Raton, Fla., CRC Press, p. 119-144.

Lübcke, P., Bobrowski, N., Illing, S., Kern, C., Alvarez Nieves, J.M., Vogel, L., Zielcke, J., Delgado Granados, H., and Platt, U., 2013, On the absolute calibration of $\mathrm{SO}_{2}$ cameras: Atmospheric Measurement Techniques, v. 6, p. 677-696.

Lundgren, Paul, Poland, Michael, Miklius, Asta, Orr, Tim, Yun, Sang-Ho, Fielding, Eric, Liu, Zhen, Tanaka, Akiko, Szeliga, Walter, Hensley, Scott, and Owen, Susan, 2013, Evolution of dike opening during the March 2011 Kamoamoa fissure eruption, Kîlauea Volcano, Hawaìi: Journal of Geophysical Research Solid Earth, v. 118, p. 897-914. 
Luttrell, Karen, Mencin, David, Francis, Olivier, and Hurwitz, Shaul, 2013, Constraints on the upper crustal magma reservoir beneath Yellowstone Caldera inferred from lakeseiche induced strain observations: Geophysical Research Letters, v. 40, p. 501-506.

Major, J.J., 2013, Stress, deformation, conservation, and rheology-A survey of key concepts in continuum mechanics, in Schroder, J., Marston, R.A., and Stoffel, M., eds., Treatise on geomorphology, v. 7, Mountain and hillslope geomorphology: San Diego, Academic Press, p. 20-43.

Major, J.J., and Lara, L.E., 2013, Overview of Chaitén Volcano, Chile, and its 20082009 eruption: Andean Geology, v. 40, p. 196-215.

Major, J.J., Pierson, T.C., Hoblitt, R.P., and Moreno, Hugo, 2013, Pyroclastic density currents associated with the 2008-2009 eruption of Chaitén Volcano (Chile)—Forest disturbances, deposits, and dynamics: Andean Geology, v. 40, p. 324-358.

Manville, Vernon, Major, J.J, and Fagents, S.A., 2013, Modeling lahar behavior and hazards, chap. 14 of Fagents, S.A., Gregg, T.K.P., and Lopes, R.M.C., eds., Modeling volcanic processes - The physics and mathematics of volcanism: New York, Cambridge University Press, p. 300-330.

Massin, Frédérick, Farrell, Jamie, and Smith, R.B., 2013, Repeating earthquakes in the Yellowstone volcanic field-Implications for rupture dynamics, ground deformation, and migration in earthquake swarms: Journal of Volcanology and Geothermal Research, v. 257, p. 159-173.

Mastin, L.G., Randall, M.J., Schwaiger, H.F., and Denlinger, R.P., 2013, User's guide and reference to Ash3d-A three-dimensional model for Eulerian atmospheric tephra transport and deposition: U.S. Geological Survey Open-File Report 2013-1122, 48 p., http://pubs.usgs.gov/of/2013/1122/.

Mastin, L.G., Schwaiger, Hans, Schneider, D.J., Wallace, K.L., Schaefer, Janet, and Denlinger, R.P., 2013, Injection, transport, and deposition of tephra during event 5 at Redoubt Volcano, 23 March, 2009, in Waythomas, C.F., and Webley, P.W., eds., The 2009 eruption of Redoubt Volcano, Alaska: Journal of Volcanology and Geothermal Research, v. 259, p. 201-213.

Mathie, A.M., and Wood, Nathan, 2013, Residential and service-population exposure to multiple natural hazards in the Mount Hood region of Clackamas County, Oregon: U.S. Geological Survey Open-File Report 2013-1073, 48 p., http://pubs.usgs.gov/of/2013/1073/.

Matoza, R.S., Shearer, P.M., Lin, Guoqing, Wolfe, C.J., and Okubo, P.G., 2013, Systematic relocation of seismicity on Hawaii Island from 1992 to 2009 using waveform cross correlation and cluster analysis: Journal of Geophysical Research Solid Earth, v. 118, p. 2275-2288.

McNutt, S.R., Thompson, G., West, M.E., Fee, D., Stihler, S., and Clark, E., 2013, Local seismic and infrasound observations of the 2009 explosive eruptions of Redoubt Volcano, Alaska, in Waythomas, C.F., and Webley, P.W., eds., The 2009 eruption of Redoubt Volcano, Alaska: Journal of Volcanology and Geothermal Research, v. 259, p. 63-76.

Montgomery-Brown, E.K., Thurber, C.H., Wolfe, C.J., and Okubo, P., 2013, Slow slip and tremor search at Kilauea Volcano, Hawaii: Geochemistry, Geophysics, Geosystems, v. 14, p. 367-384. 
Nathenson, Manuel, 2013, Publications of the Volcano Hazards Program 2011: U.S. Geological Survey Open-File Report 2013-1164, 9 p., http://pubs.usgs.gov/of/2013/1164/.

Nathenson, Manuel, and Mariner, R.H., 2013, Springs, streams, and gas vent on and near Mount Adams volcano, Washington: U.S. Geological Survey Scientific Investigations Report 2013-5097, 19 p., http://pubs.usgs.gov/sir/2013/5097/.

Orr, T.R., Heliker, Christina, and Patrick, M.R., 2013, The ongoing Pu'u 'O'o eruption of Kīlauea Volcano, Hawai' i -30 years of eruptive activity: U.S. Geological Survey Fact Sheet 2012-3127, 6 p., http://pubs.usgs.gov/fs/2012/3127/.

Orr, T.R., Thelen, W.A., Patrick, M.R., Swanson, D.A., and Wilson, D.C., 2013, Explosive eruptions triggered by rockfalls at Kîlauea volcano, Hawai' $i$ i: Geology, v. 41, p. 207-210, time-lapse videos.

Pallister, J.S., Cashman, K.V., Hagstrum, J.T., Beeler, N.M., Moran, S.C., and Denlinger, R.P., 2013, Faulting within the Mount St. Helens conduit and implications for volcanic earthquakes: Geological Society of America Bulletin, v. 125, p. 359-376.

Pallister, J.S., Diefenbach, A.K., Burton, W.C., Muñoz, Jorge, Griswold, J.P., Lara, L.E., Lowenstern, J.B., and Valenzuela, C.E., 2013, The Chaitén rhyolite lava domeEruption sequence, lava dome volumes, rapid effusion rates and source of the rhyolite magma: Andean Geology, v. 40, p. 277-294.

Pallister, J.S., Schneider, D.J., Griswold, J.P., Keeler, R.H., Burton, W.C., Noyles, Christopher, Newhall, C.G., and Ratdomopurbo, Antonius, 2013, Merapi 2010 eruption - Chronology and extrusion rates monitored with satellite radar and used in eruption forecasting, in Jousset, Philippe, Pallister, John, and Surono, eds., The 2010 eruption of Merapi volcano: Journal of Volcanology and Geothermal Research, v. 261, p. 144-152.

Parcheta, C.E., Houghton, B.F., and Swanson, D.A., 2013, Contrasting patterns of vesiculation in low, intermediate, and high Hawaiian fountains - A case study of the 1969 Mauna Ulu eruption: Journal of Volcanology and Geothermal Research, v. 255, p. 79-89.

Patrick, Matthew, Orr, Tim, Sutton, A.J., Elias, Tamar, and Swanson, Don, 2013, The first five years of Kīlauea's summit eruption in Halema'uma'u Crater, 2008-2013: U.S. Geological Survey Fact Sheet 2013-3116, 4 p., http://pubs.usgs.gov/fs/2013/3116/.

Pfeffer, M.A., Doukas, M.P., Werner, C.A., and Evans, W.C., 2013, Airborne filter pack measurements of $\mathrm{S}$ and $\mathrm{Cl}$ in the plume of Redoubt Volcano, Alaska February-May 2009, in Waythomas, C.F., and Webley, P.W., eds., The 2009 eruption of Redoubt Volcano, Alaska: Journal of Volcanology and Geothermal Research, v. 259, p. 285289.

Pierson, T.C., 2013, Using age of colonizing Douglas-fir for the dating of young geomorphic surfaces-A case study, in Schneuwly-Bollschweiler, M., Stoffel, M., and Rudolf-Miklau, F., eds., Dating torrential processes on fans and cones: Dordrecht, Springer, p. 203-210.

Pierson, T.C., Driedger, C.L., and Tilling, R.I., 2013, Volcano crisis response at Yellowstone volcanic complex-After-action report for exercise held at Salt Lake City, Utah, November 15, 2011: U.S. Geological Survey Open-File Report 2013-1018, 31 p., http://pubs.usgs.gov/of/2013/1018/. 
Pierson, T.C., Major, J.J., Amigo, Álvaro, and Moreno, Hugo, 2013, Acute sedimentation response to rainfall following the explosive phase of the 2008-2009 eruption of Chaitén volcano, Chile: Bulletin of Volcanology, v. 75, article 723, 17 p.

Plattner, C., Amelung, F., Baker, S., Govers, R., and Poland, M., 2013, The role of viscous magma mush spreading in volcanic flank motion at Kīlauea Volcano, Hawai‘ $i$ : Journal of Geophysical Research Solid Earth, v. 118, p. 2474-2487.

Poland, M.P., Okubo, P.G., and Hon, Ken, 2013, Exploring Hawaiian volcanism-AGU Chapman Conference: Hawaiian Volcanoes, From Source to Surface; Waikoloa, Hawai‘i, 20-24 August 2012: Eos Transactions American Geophysical Union, v. 94, no. 7 , p. 72.

Power, J.A., Stihler, S.D., Chouet, B.A., Haney, M.M., and Ketner, D.M., 2013, Seismic observations of Redoubt Volcano, Alaska-1989-2010 and a conceptual model of the Redoubt magmatic system, in Waythomas, C.F., and Webley, P.W., eds., The 2009 eruption of Redoubt Volcano, Alaska: Journal of Volcanology and Geothermal Research, v. 259, p. 31-44.

Richter, Nicole, Poland, M.P., and Lundgren, P.R., 2013, TerraSAR-X interferometry reveals small-scale deformation associated with the summit eruption of Kîlauea Volcano, Hawai'i: Geophysical Research Letters, v. 40, p. 1279-1283.

Schaefer, J.R., Scott, W.E., Evans, W.C., Wang, Bronwen, and McGimsey, R.G., 2013, Summit crater lake observations, and the location, chemistry, and $\mathrm{pH}$ of water samples near Mount Chiginagak volcano, Alaska: 2004-2012: Alaska Division of Geological and Geophysical Surveys Report of Investigation 2011-6 v.2, 25 p., accessed May 15, 2015, at http://www.dggs.alaska.gov/pubs/id/25602.

Schneider, D.J., and Hoblitt, R.P., 2013, Doppler weather radar observations of the 2009 eruption of Redoubt Volcano, Alaska, in Waythomas, C.F., and Webley, P.W., eds., The 2009 eruption of Redoubt Volcano, Alaska: Journal of Volcanology and Geothermal Research, v. 259, p. 133-144.

Searcy, Cheryl, 2013, Seismicity associated with the May 2010 eruption of South Sarigan Seamount, Northern Mariana Islands: Seismological Research Letters, v. 84, p. 10551061.

Shelly, David, 2013, Tectonic tremor, in Bobrowsky, P.T., ed., Encyclopedia of Natural Hazards: Dordrecht, The Netherlands, Springer, p. 1004-1006.

Shelly, D.R., Hill, D.P., Massin, Frédérick, Farrell, Jamie, Smith, R.B., and Taira, Taka'aki, 2013, A fluid-driven earthquake swarm on the margin of the Yellowstone caldera: Journal of Geophysical Research Solid Earth, v. 118, p. 4872-4886.

Shelly, D.R., Moran, S.C., and Thelen, W.A., 2013, Evidence for fluid-triggered slip in the 2009 Mount Rainier, Washington earthquake swarm: Geophysical Research Letters, v. 40, p. 1506-1512.

Sherrod, D.R., Magigita, M.M., and Kwelwa, Shimba, 2013, Geologic map of Oldonyo Lengai (Oldoinyo Lengai) volcano and surroundings, Arusha Region, United Republic of Tanzania: U.S. Geological Survey Open-File Report 2013-1306, 65 p., 1 plate, scale 1:50,000, database, http://pubs.usgs.gov/of/2013/1306/.

Sisson, T.W., and Moore, J.G., 2013, Geologic map of southwestern Sequoia National Park, Tulare County, California: U.S. Geological Survey Open-File Report 2013-1096, 26 p., 2 sheets, scale 1:24,000, http://pubs.usgs.gov/of/2013/1096/. 
Steensen, T., Stuefer, M., Webley, P., Grell, G., and Freitas, S., 2013, Qualitative comparison of Mount Redoubt 2009 volcanic clouds using the PUFF and WRF-Chem dispersion models and satellite remote sensing data, in Waythomas, C.F., and Webley, P.W., eds., The 2009 eruption of Redoubt Volcano, Alaska: Journal of Volcanology and Geothermal Research, v. 259, p. 235-247.

Stelten, M.E., Cooper, K.M., Vazquez, J.A., Reid, M.R., Barfod, G.H., Wimpenny, Josh, and Yin, Qing-Zhu, 2013, Magma mixing and the generation of isotopically juvenile silicic magma at Yellowstone caldera inferred from coupling ${ }^{238} \mathrm{U}_{-}{ }^{230} \mathrm{Th}$ ages with trace elements and $\mathrm{Hf}$ and $\mathrm{O}$ isotopes in zircon and $\mathrm{Pb}$ isotopes in sanidine:

Contributions to Mineralogy and Petrology, v. 166, p. 587-613.

Stewart, Carol, Horwell, Claire, Plumlee, Geoff, Cronin, Shane, Delmelle, Pierre, Baxter, Peter, Calkins, Julie, Damby, David, Morman, Suzette, and Oppenheimer, Clive, 2013, Protocol for analysis of volcanic ash samples for assessment of hazards from leachable elements: International Volcanic Health Hazard Network, 21 p., accessed July 1, 2013, at http://www.ivhhn.org.

Thelen, W.A., Allstadt, Kate, De Angelis, Silvio, Malone, S.D., Moran, S.C., and Vidale, John, 2013, Shallow repeating seismic events under an alpine glacier at Mount Rainier, Washington, USA: Journal of Glaciology, v. 59, p. 345-356.

Till, C.B., Grove, T.L., Carlson, R.W., Fouch, M.J., Donnelly-Nolan, J.M., Wagner, L.S., and Hart, W.K., 2013, Depths and temperatures of $<10.5$ Ma mantle melting and the lithosphere-asthenosphere boundary below southern Oregon and northern California: Geochemistry, Geophysics, Geosystems, v. 14, p. 864-879.

Tilling, R.I., 2013, Preface, in Carracedo, J.C., and Trool, V.R., eds., Teide VolcanoGeology and eruptions of a highly differentiated oceanic stratovolcano: Heidelberg, Springer, p. v-vi.

Underwood, S.J., Feeley, T.C., and Clynne, M.A., 2013, Hydrogen isotope investigation of amphibole and glass in dacite magmas erupted in 1980-1986 and 2005 at Mount St. Helens, Washington: Journal of Petrology, v. 54, p. 1047-1070.

Van Hoose, A.E., Streck, M.J., Pallister, J.S., and Wälle, Markus, 2013, Sulfur evolution of the 1991 Pinatubo magmas based on apatite: Journal of Volcanology and Geothermal Research, v. 257, p. 72-89.

Waitt, R.B., 2013, Lahar, in Bobrowsky, P.T., ed., Encyclopedia of Natural Hazards: Dordrecht, The Netherlands, Springer, p. 579-580.

Wallace, K.L., Schaefer, J.R., and Coombs, M.L., 2013, Character, mass, distribution, and origin of tephra-fall deposits from the 2009 eruption of Redoubt Volcano, Alaska-Highlighting the significance of particle aggregation, in Waythomas, C.F., and Webley, P.W., eds., The 2009 eruption of Redoubt Volcano, Alaska: Journal of Volcanology and Geothermal Research, v. 259, p. 145-169.

Wauthier, C., Cayol, V., Poland, M., Kervyn, F., d'Oreye, N., Hooper, A., Samsonov, S., Tiampo, K., and Smets, B., 2013, Nyamulagira's magma plumbing system inferred from 15 years of InSAR, in Pyle, D.M., Mather, T.A., and Biggs, J., eds., Remote sensing of volcanoes and volcanic processes - Integrating observation and modelling: Geological Society of London Special Publication 380, p. 39-65.

Wauthier, Christelle, Roman, D.C., and Poland, M.P., 2013, Moderate-magnitude earthquakes induced by magma reservoir inflation at Kîlauea Volcano, Hawai'i: Geophysical Research Letters, v. 40, p. 5366-5370. 
Waythomas, C.F., and Webley, P.W., eds., 2013, The 2009 eruption of Redoubt Volcano, Alaska: Journal of Volcanology and Geothermal Research, v. 259, 423 p.

Waythomas, C.F., and Webley, P.W., 2013, Preface to the special issue of JVGR on the 2009 eruption of Redoubt Volcano, Alaska, in Waythomas, C.F., and Webley, P.W., eds., The 2009 eruption of Redoubt Volcano, Alaska: Journal of Volcanology and Geothermal Research, v. 259, p. 1.

Waythomas, C.F., Pierson, T.C., Major, J.J., and Scott, W.E., 2013, Voluminous ice-rich and water-rich lahars generated during the 2009 eruption of Redoubt Volcano, Alaska, in Waythomas, C.F., and Webley, P.W., eds., The 2009 eruption of Redoubt Volcano, Alaska: Journal of Volcanology and Geothermal Research, v. 259, p. 389-413.

Webley, P.W., Lopez, T.M., Ekstrand, A.L., Dean, K.G., Rinkleff, P., Dehn, J., Cahill, C.F., Wessels, R.L., Bailey, J.E., Izbekov, P., and Worden, A., 2013, Remote observations of eruptive clouds and surface thermal activity during the 2009 eruption of Redoubt volcano, in Waythomas, C.F., and Webley, P.W., eds., The 2009 eruption of Redoubt Volcano, Alaska: Journal of Volcanology and Geothermal Research, v. 259, p. 185-200.

Weinstein, Yishai, Weinberger, Ram, and Calvert, Andrew, 2013, High-resolution ${ }^{40} \mathrm{Ar} /{ }^{39} \mathrm{Ar}$ study of Mount Avital, northern Golan-Reconstructing the interaction between volcanism and a drainage system and their impact on eruptive styles: Bulletin of Volcanology, v. 75, article 712, 12 p.

Werner, Cynthia, Kelly, P.J., Doukas, Michael, Lopez, Taryn, Pfeffer, Melissa, McGimsey, Robert, and Neal, Christina, 2013, Degassing of $\mathrm{CO}_{2}, \mathrm{SO}_{2}$, and $\mathrm{H}_{2} \mathrm{~S}$ associated with the 2009 eruption of Redoubt Volcano, Alaska, in Waythomas, C.F., and Webley, P.W., eds., The 2009 eruption of Redoubt Volcano, Alaska: Journal of Volcanology and Geothermal Research, v. 259, p. 270-284.

Wessels, R.L., Vaughan, R.G., Patrick, M.R., and Coombs, M.L., 2013, High-resolution satellite and airborne thermal infrared imaging of precursory unrest and 2009 eruption at Redoubt Volcano, Alaska, in Waythomas, C.F., and Webley, P.W., eds., The 2009 eruption of Redoubt Volcano, Alaska: Journal of Volcanology and Geothermal Research, v. 259, p. 248-269.

Wu, C., Shelly, D.R., Gomberg, J., Peng, Z., and Johnson, P., 2013, Long-term changes of inter-event times for regular and low-frequency earthquakes in central California: Earth and Planetary Science Letters, v. 368, p. 144-150.

Zander, P.D., Kaufman, D.S., Kuehn, S.C., Wallace, K.L., and Anderson, R.S., 2013, Early and late Holocene glacial fluctuations and tephrostratigraphy, Cabin Lake, Alaska: Journal of Quaternary Science, v. 28, p. 761-771.

Zierenberg, R.A., Schiffman, P., Barford, G.H., Lesher, C.E., Marks, N.E., Lowenstern, J.B., Mortensen, A.K., Pope, E.C., Bird, D.K., Reed, M.H., Friðleifsson, G.Ó., and Elders, W.A., 2013, Composition and origin of rhyolite melt intersected by drilling in the Krafla geothermal field, Iceland: Contributions to Mineralogy and Petrology, v. 165 , p. 327-347.

Zoback, M.L., Geist, Eric, Pallister, John, Hill, D.P., Young, Simon, and McCausland, Wendy, 2013, Advances in natural hazard science and assessment, 1963-2013, in Bickford, M.E., ed., The impact of the geological sciences on society: Geological Society of America Special Paper 501, Boulder, Colorado, p. 81-154. 